\title{
LYPLA1 Gene
}

National Cancer Institute

\section{Source}

National Cancer Institute. LYPLA1 Gene. NCI Thesaurus. Code C104624.

This gene plays a role in regulating membrane lysophospholipids. 